\section{談話室 話}

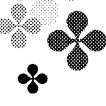

IT (Information Technology) と教育 大橋良子

昔, 図書館はとても身近な存在だった。特に研究のスタート 時, 何日間も, 終日図書館に籠って文献検索をした。まず, 検索 したい項目をキーワード版で探し, 関連する文献を年代ごとの速 報版で探してアブストラクトを読む。それからオリジナル文 献を書庫から探し出してコピーする。この根気のいる作業を 延々と続けるのだ。時にはコピーの際にパラパラと前後の論 文を見る。同じような論文でも, 研究対象や研究手法が異なっ ていて, 思いがけないヒントが得られたりする。なかなか目当 ての論文が見つからなくて, 途中で少々飽きると最新号の雑誌 で, 現在流行のテーマの動向を知ったりする。無駄の価值とも 言うべきか。

ITの発達により情報収集の方法が変わった。現在では,デー タベースに適当なキーワードを組み合わせて検索すると, 一瞬 にして10の何乗ものオーダーで文献がリストアップされ,アブ ストラクトも出る。オリジナル版も PDFファイルでただちに 取り込める。

しかも研究室のパソコンで24時間これができるのだ。時間 的な効率の向上は計り知れない。ただし，どの論文を選ぶかは， 検索者の判断による。キーワードの組み合わせ方など検索技 術により, ある程度は短縮できるが, 数が多ければやはり時間 はかかる。逆に昔のような寄り道はできないだろう。

IT に関連して, 筆者のごく狭い範囲の経験からではあるが,
最近では大学教育についても授業のあり方を根本的に考え直 さなくてはならないと感じている。従来型の講義, いわゆるレ クチャーによる知識の伝達は，もう不要なのではないだろうか。 学術文献に限らず, 例えばgoogleなどで, あらゆることが検索 できるのだから。実際, 学生との雑談の中でもレクチャー不要論 が出た。ただし, 検索で得られた情報を鵜吞みにせず, 適切に 評価する必要があり，これはなかなか難しい。これからのレク チャーの役割は,コンパクトに体系化した知識を効率良く伝達 し, 情報を適切に判断するための基盤を作ることであろう。大学 教育は,このようなレクチャーとともに, レッスンやディスカ ッションを中心にする必要があるのではないだろうか。まず, レッスンでは, 基礎的な知識を定着させ, 使えるレベルにする 必要がある。そのためには基礎的な知識を繰り返し使い, また応 用するトレーニングが中心となる。定着した知識を使えるレ ベルにするには時間がかかる。知っていることと, 使えること の間にはギャップがあるのだ。何が基礎的で, どのように使う かは各々のレベルによって異なるが,いずれにせよいろいろな 知識を吸収したあとで, 再編する頭脳作業が必要ではないかと 思う。ここで, 理解力が高まる。デイスカッションでは, この 再編する頭脳作業をグループで行うことにより，お互いに刺激 し合ってさらに発展させ, 創造性を高めることができると期待さ れる。この過程で思考力はもとより, 表現力も培われることであ ろう。

これらのスキルを身につけたIT社会の若者の活躍を楽しみ に見守っていきたいものである。

「談話室」では皆様からの原稿を随時募集しております。原則として 内容は問いません。積極的なで寄稿をお待ちいたしております。 (なお, 掲載の可否につきましては, 編集委員会にで一任いただきま すようお願い申し上げます。) 